\title{
Adhesion to brown trout skin mucus, antagonism against cyst adhesion and pathogenicity to rainbow trout of some inhibitory bacteria against Saprolegnia parasitica
}

\author{
M. T. Carbajal-González, J. M. Fregeneda-Grandes, C. González-Palacios, \\ J. M. Aller-Gancedo*
}

Departamento de Sanidad Animal, Facultad de Veterinaria, Universidad de León, 24071 León, Spain

\begin{abstract}
Biological control of saprolegniosis with bacteria might be an alternative to the use of chemical compounds. Among criteria for the selection of such bacteria are their absence of pathogenicity to fish and their ability to prevent adhesion of the pathogen to the skin mucus. The pathogenicity to rainbow trout of 21 bacterial isolates with in vitro inhibitory activity against Saprolegnia parasitica was studied. Fifteen of the isolates, identified as Aeromonas sobria, Pantoea agglomerans, Pseudomonas fluorescens, Serratia fonticola, Xanthomonas retroflexus and Yersinia kristensenii, were non-pathogenic when injected into rainbow trout. Their capacity to adhere to the skin mucus of male and female brown trout and to reduce the adhesion of $S$. parasitica cysts under exclusion, competition and displacement conditions was tested. The 15 bacterial isolates showed a low adhesion rate, ranging between $1.7 \%$ (for an A. sobria isolate) and $15.3 \%$ (a P. fluorescens isolate). This adhesion was greater in the case of mucus from male brown trout than from females. Similarities in the adhesion to male mucus and other substrates and correlation to that observed to polystyrene suggest that adhesion to skin mucus does not depend on the substrate. A high percentage $(88.9 \%)$ of the $S$. parasitica cysts adhered to the skin mucus of male brown trout. Almost all of the bacteria reduced this adhesion ratio significantly under exclusion and competition conditions. However, only half of the isolates displaced cysts from skin mucus, and more bacterial cells were necessary for this effect. A novel method to study the adhesion of $S$. parasitica cysts to skin mucus of trout and their interactions with inhibitory bacteria is described.
\end{abstract}

KEY WORDS: Saprolegniosis $\cdot$ Epidermal biota $\cdot$ Mucin $\cdot$ Binding ability $\cdot$ Salmo trutta

\section{INTRODUCTION}

Saprolegniosis is a tegumentary disease of freshwater fish which can be observed by the presence of cotton-like tufts and ulcers on the skin. It is caused by members of the genus Saprolegnia, which nowadays is clasified into the kingdom Chromista. To prevent and control salmonid saprolegniosis in fish farms, different chemical compounds are used. Independently of their efficacy, the inappropriate use of these products has a potential risk for public health and for the environment.
One of the alternatives that is gaining increasing attention, apart from the use of natural substances such as essential oils (Muzzarelli et al. 2001, Khosravi et al. 2012), is the biological control of saprolegniosis. The in vitro inhibitory effects of some bacteria against Saprolegnia spp. have been described in several studies (Hatai \& Willoughby 1988, Bly et al. 1997, Hussein \& Hatai 2001, Lategan \& Gibson 2003, Zhang et al. 2008, Nurhajati et al. 2012, Ran et al. 2012).

Carbajal-González et al. (2011) found that certain bacteria from the skin of brown trout Salmo trutta 
and rainbow trout Oncorhynchus mykiss can inhibit or render difficult the in vitro growth of Saprolegnia parasitica. Hence some of these bacteria might be useful in the biological control of saprolegniosis. Saprolegnia spp. infections are produced mainly via the skin; therefore, the skin mucus is the first barrier that $S$. parasitica must overcome if the skin is not cut or abraded. The ability of some potential probiotic bacteria to adhere to the skin and intestinal mucus of various fish species and to reduce the binding of some pathogens has previously been investigated (Nikoskelainen et al. 2001, Vine et al. 2004, Chabrillón et al. 2005, 2006, Balcázar et al. 2007, 2008, Sica et al. 2012).

In the present study, we tested the absence of pathogenicity of a selection of inhibitory bacteria of Saprolegnia parasitica against rainbow trout. This was followed up by testing the effectiveness of the benign strains to adhere to the skin mucus of trout, and to reduce the adhesiveness of $S$. parasitica cysts when pre-inoculated (exclusion), added with the cysts (competition) or added after them (displacement). These studies will enable suitable bacterial isolates that may be of use in the biological control of saprolegniosis to be identified for further study.

\section{MATERIALS AND METHODS}

\section{Pathogenicity for rainbow trout}

Fish and bacterial isolates

Rainbow trout Oncorhynchus mykiss were obtained from a commercial fish farm in the Province of León in Spain. The weight of the fish was $53 \pm 16.2 \mathrm{~g}$ (mean $\pm \mathrm{SD}$ ) in the first challenge and $28.7 \pm 9.2 \mathrm{~g}$ in the second. They were maintained for at least $10 \mathrm{~d}$ in aerated, free-flowing well water at $15^{\circ} \mathrm{C}$ so as to ensure their acclimatization.

We used 21 bacterial isolates which had been obtained from healthy skin and from saprolegniosis lesions of brown trout and healthy rainbow trout collected from rivers and fish farms in the Province of León. These isolates, which had shown a high inhibitory activity against Saprolegnia parasitica mycelium in previous in vitro assays, belonged to the species Aeromonas popoffii (2 isolates), A. sobria (7), Pantoea agglomerans (3), Pseudomonas fluorescens (5), Serratia fonticola (1), Xanthomonas retroflexus (1) and Yersinia kristensenii (2) (Carbajal-Gonzáles et al. 2011, their Table 3; A. salmonicida and A. piscicola were rejected).

\section{Challenge to fish}

To test the absence of pathogenicity of the bacteria to rainbow trout, 2 serial challenges were carried out: the first to eliminate any pathogenic bacteria and the second to confirm, with a larger number of fish, that these bacteria were actually non-pathogenic.

The bacterial isolates were grown in tryptone soy broth (Cultimed) at $20^{\circ} \mathrm{C}$ overnight. The cells were harvested by centrifugation at $1000 \times g(10 \mathrm{~min}$ at $\left.4^{\circ} \mathrm{C}\right)$, re-suspended in saline solution $(0.9 \% \mathrm{NaCl}$ $\mathrm{w} / \mathrm{v}$ ), counted in a haemocytometer chamber (Improved Neubauer Type, Albert Sass) at a magnification of $400 \times$ and adjusted to $10^{7}$ cells $\mathrm{ml}^{-1}$. A volume of $0.1 \mathrm{ml}$ was injected intraperitoneally (i.p.) and intramuscularly (i.m.) into separate groups of 5 trout for the first challenge and 20 trout for the second. Control groups of 5 trout for the first challenge and 20 for the second were injected at the same points with $0.1 \mathrm{ml}$ of saline solution. All fish were maintained under the same conditions in $40 \mathrm{l}$ tanks at a flow rate of approximately $11 \mathrm{~min}^{-1}$. The dead and moribund fish and the survivors after $10 \mathrm{~d}$ (first challenge) or after $14 \mathrm{~d}$ (second challenge) were examined for evidence of disease. Loopfuls of material from the kidney, liver and spleen were spread over plates of tryptone soy agar (Cultimed) with incubation at $20^{\circ} \mathrm{C}$ for $7 \mathrm{~d}$ to determine the presence or absence of the inoculated bacterial isolates in the fish. The bacterial isolates recovered were examined by means of Gram-stained smears and biochemical tests (API $20 \mathrm{E}$ and API20 NE, Biomerieux®).

\section{Assays of adhesion to skin mucus}

Bacteria and Saprolegnia isolates and skin mucus

We selected the 15 bacterial isolates that showed no pathogenicity, as determined in the previous assays. They belonged to the genera Aeromonas (3 isolates), Pantoea (3), Pseudomonas (5), Serratia (1), Xanthomonas (1) and Yersinia (2). The isolate of Saprolegnia parasitica Tru8, which was obtained from a wild brown trout with saprolegniosis (Fregeneda-Grandes et al. 2000), was used for these assays. Zoospores and cysts were obtained as described by Fregeneda-Grandes et al. (2000), that is, by incubating hemp seed halves previously colonized by $S$. parasitica in sterile and filtered river water for $36 \mathrm{~h}$ at $20^{\circ} \mathrm{C}$ and harvesting them.

Healthy male and female brown trout (4 specimens of each sex) were obtained from a hatchery belong- 
ing to the Regional Government of Castile and Léon (Junta de Castilla y León), to prepare separate pools of skin mucus for the assays. Fish with body weights of $138.6 \pm 76.5 \mathrm{~g}$ were carried alive to the laboratory and sacrificed by a blow to the head. The skin mucus was immediately collected into a Petri dish from the whole body by scraping the surfaces with a plastic spatula. Then it was removed from the plate into a centrifuge tube with the aid of a small amount of phosphate-buffered saline (PBS), and was centrifuged twice at $12000 \times g\left(5 \mathrm{~min}\right.$ at $\left.4^{\circ} \mathrm{C}\right)$ to remove particulate and cellular debris. The protein concentration was determined using Bradford reagent (Sigma) and bovine serum albumin (BSA; Sigma) as a standard. Preparations were then adjusted to a protein concentration of $0.5 \mathrm{mg} \mathrm{ml}^{-1}$ in PBS. This mucus suspension was finally sterilized by UV light exposure for $30 \mathrm{~min}$ and stored in aliquots at $-20^{\circ} \mathrm{C}$ until use.

Labelling of bacteria and cysts and adhesion assays

Bacteria and cysts of Saprolegnia parasitica were stained with the green fluorescent nucleic acid stain Syto 9 (Invitrogen) at a concentration of $1 \mu \mathrm{l}$ per $10^{9}$ bacteria in $1 \mathrm{ml}$ and $1 \mu \mathrm{l}$ per $10^{5}$ cysts in $1 \mathrm{ml}$. After the stain had been added to the bacterial or cyst suspensions in sterile saline solution, the bacteria and cysts were pelleted by centrifugation at $10500 \times$ $g$ (10 $\mathrm{min})$ to remove the supernatant and resuspended in $1 \mathrm{ml}$ of fresh saline solution. They were spectrophotometrically analysed in a Genios (Tecon) microplate reader (485 nm excitation, $535 \mathrm{~nm}$ emission).

Trout skin mucus preparations (25 $\mu \mathrm{l})$ were diluted $1 / 10$ (so that the final protein concentration was $0.05 \mathrm{mg} \mathrm{ml}^{-1}$ ) and added in triplicate to a 96-well black polystyrene plate (Costar). Both male and female brown trout skin mucus was tested. As indicators of unspecific adhesion, BSA $\left(0.05 \mathrm{mg} \mathrm{ml}^{-1}\right)$ and mucin from porcine stomach Type II (MPS; $0.05 \mathrm{mg}$ $\mathrm{ml}^{-1}$, Sigma) were used. Then, $75 \mu$ l of coating buffer (16.8 g sodium hydrogen carbonate, $21.2 \mathrm{~g}$ sodium carbonate per litre, $\mathrm{pH}$ 9.6) was added to each well and left overnight at $4^{\circ} \mathrm{C}$. After washing with PBSTween $20(0.1 \%), 25 \mu \mathrm{l}$ of fluorescently labelled bacterial solution $\left(10^{9}\right.$ bacterial cells $\left.\mathrm{ml}^{-1}\right)$ was added to the coated wells and also to wells without coating, to test adhesion to polystyrene. Bacteria were forced to the bottom of the plate by centrifugation $(163 \times g$, $12 \mathrm{~s})$ and incubated for $30 \mathrm{~min}$ in the dark at room temperature, and then the fluorescence generated by labelled bacteria was recorded with a Genios (Tecon) microplate reader as described above. This was considered the measurement at time 0 (T0). After this, plates were washed with saline solution to remove non-attached bacteria, and the remaining liquid was removed by centrifugation of the plates upside down on an absorbent paper. A second spectrophotometrical measurement was done after adding $50 \mu \mathrm{l}$ of saline solution to the wells. Adhesion was expressed as the percentage of fluorescence recovered in the second measurement relative to the fluorescence at T0. Binding of the mucus to the plate was confirmed by a lectin-binding assay as described by Neuhaus et al. (2007), using Dolichos biflorus lectin (DBA, Sigma).

For the adhesion assays with the cysts of Saprolegnia parasitica, the same 96-well black polystyrene plates coated with the skin mucus of male and female brown trout were used in triplicate. The steps followed in the assays were the same as those described above but using fluorescently stained cyst suspension instead of bacteria. Adhesion was expressed as the percentage of fluorescence of the bound cysts in the second measurement relative to the fluorescence of the cysts at $\mathrm{T} 0$.

\section{Exclusion, competition and displacement tests}

For these tests, non-stained bacteria were prepared at an initial concentration of $10^{9}$ bacterial cells $\mathrm{ml}^{-1}$ in saline solution, and a further 7 serial 10 -fold dilutions were done. The cysts were stained as described above, and the concentration used for the assays was $10^{5}$ cysts $\mathrm{ml}^{-1}$. The same 96 -well plates were coated only with male trout mucus for these assays, as the incidence of saprolegniosis is higher in males (Aller-Gancedo \& Fernández-Díez 1987). For the exclusion test, $25 \mu \mathrm{l}$ of each dilution of the bacterial isolates was added to the wells and incubated for $30 \mathrm{~min}$ at room temperature. After a wash with saline solution to remove non-adhered cells, a $25 \mu$ quantity of labelled cysts was added, and the plates were incubated for another $30 \mathrm{~min}$ at room temperature. For the competition test, $25 \mu \mathrm{l}$ of each bacterial dilution and $25 \mu \mathrm{l}$ of stained cysts were added simultaneously to the wells and incubated for $60 \mathrm{~min}$ at room temperature. For the displacement test, the labelled cyst suspension was first added to the wells and incubated for $30 \mathrm{~min}$ at room temperature. After a wash with saline solution to remove non-attached cysts, each dilution of the bacterial suspension was added and the plates were incubated for another $30 \mathrm{~min}$ at 
room temperature. After $60 \mathrm{~min}$ of incubation for each condition, plates were washed with saline solution and the adhesion ratio (\%) was calculated as described above. As a control for each condition, wells with saline solution instead of bacterial cells were prepared. The percentage of cysts bound to these control wells was considered as the reference value $(100 \%)$.

\section{Statistical analysis}

All results are shown as the average of at least 3 independent experiments; variation is expressed as standard deviation. A paired Student's t-test and a Student's $t$-test were used to determine whether the adhesion of bacteria to the various substrates tested differed significantly $(\mathrm{p}<0.05)$. The Pearson correlation coefficient was calculated to determine any possible relationship between adhesion to polystyrene and to male skin mucus.

For the exclusion, competition and displacement tests, the differences in adhesion of the cysts to the skin mucus, with or without bacteria, were considered significant when $\mathrm{p}<0.05$ with the Student's $t$ test. All the statistics were calculated using SPSS for Windows version 16.0 and Microsoft Excel 2003.

\section{RESULTS}

\section{Pathogenicity for rainbow trout}

Results of both challenges performed are summarised in Table 1. In the first challenge with the 21 bacterial isolates, 15 were considered non-pathogenic for rainbow trout, as there was no mortality or signs of disease following the im or ip inoculation. These isolates belonged to the species Aeromonas sobria (3 isolates), Pantoea agglomerans (3), Pseudomonas fluorescens (5), Serratia fonticola (1), Xanthomonas retroflexus (1) and Yersinia kristensenii (2). The remaining bacterial isolates, Aeromonas popoffii (2) and Aeromonas sobria (4), caused 20 to $40 \%$ mortality and/or macroscopic lesions in internal organs, especially in the liver and spleen. All bacteria were recovered from the internal organs.

The 15 non-pathogenic isolates from the first challenge proved non-pathogenic again when challenged against rainbow trout for a second time. When the fish were sacrificed after $14 \mathrm{~d}, 7$ out of the these 15 bacterial isolates were recovered once again in a small number of fish from the point of i.m. inoculation; with the exception of a single fish, no bacteria were re-isolated from internal organs (Table 1). None of these trout in which the inoculated bacteria were

Table 1. Oncorhynchus mykiss. Pathogenicity to rainbow trout of 21 bacterial isolates after intramuscular (i.m.) or intraperitoneal (i.p.) injection with $10^{6}$ cells. Mortality and re-isolation of bacteria from trout show the results of the challenge in 10 $(5+5)$ fish with the first 6 isolates and in 10 plus a further $40(20+20)$ fish with the remaining 15 isolates

\begin{tabular}{|c|c|c|c|c|c|}
\hline \multirow[t]{2}{*}{ Species } & \multirow[t]{2}{*}{ Isolate } & \multicolumn{2}{|c|}{ Mortality (\%) } & \multirow[t]{2}{*}{ Gross lesions } & \multirow{2}{*}{$\begin{array}{l}\text { Re-isolation of bacteria } \\
\text { (\% and tissue) }\end{array}$} \\
\hline & & i.m. & i.p. & & \\
\hline Aeromonas popoffii & LE 65 & 10 & 20 & Yes & 100 (liver, kidney, spleen) \\
\hline Aeromonas popoffii & LE 69 & 0 & 20 & No & 20 (liver, kidney, spleen) \\
\hline Aeromonas sobria & LE 17 & 20 & 20 & Yes & 50 (liver, kidney, spleen) \\
\hline Aeromonas sobria & LE 68 & 0 & 30 & No & 30 (liver, kidney, spleen) \\
\hline Aeromonas sobria & LE 100 & 0 & 30 & No & 30 (liver, kidney, spleen) \\
\hline Aeromonas sobria & LE 104 & 0 & 30 & Yes & 10 (liver, kidney, spleen) \\
\hline Aeromonas sobria & LE 51 & 0 & 0 & No & 0 \\
\hline Aeromonas sobria & LE 74 & 0 & 0 & No & 0 \\
\hline Aeromonas sobria & LE 76 & 0 & 0 & No & 0 \\
\hline Pantoea agglomerans & LE 35 & 0 & 0 & No & 0 \\
\hline Pantoea agglomerans & LE 36 & 0 & 0 & No & 0 \\
\hline Pantoea agglomerans & LE 37 & 0 & 0 & No & 45 (muscle) \\
\hline Pseudomonas fluorescens & LE 89 & 0 & 0 & No & 0 \\
\hline Pseudomonas fluorescens & LE 98 & 0 & 0 & No & 10 (muscle) \\
\hline Pseudomonas fluorescens & LE 122 & 0 & 0 & No & 0 \\
\hline Pseudomonas fluorescens & LE 141 & 0 & 0 & No & 15 (muscle) \\
\hline Pseudomonas fluorescens & LE 143 & 0 & 0 & No & 40 (muscle) \\
\hline Serratia fonticola & LE 52 & 0 & 0 & No & 10 (muscle) \\
\hline Xanthomonas retroflexus & LE 38 & 0 & 0 & No & 30 (muscle), 5 (kidney) \\
\hline Yersinia kristensenii & LE 54 & 0 & 0 & No & 0 \\
\hline Yersinia kristensenii & LE 58 & 0 & 0 & No & 10 (muscle) \\
\hline
\end{tabular}


once again isolated showed signs of disease or macroscopically visible changes.

\section{Adhesion assays}

\section{Adhesion of bacteria and Saprolegnia parasitica cysts to skin mucus}

The results for the adhesion of bacteria to brown trout skin mucus are shown in Table 2. Adhesion to male brown trout skin mucus was low for the 15 bacterial isolates tested, ranging from $1.7 \%$ of the bacterial cells (Aeromonas sobria LE 76) to 15.3\% (Pseudomonas fluorescens LE 141). The adhesion of bacteria to skin mucus of male brown trout was higher than the adhesion to female skin mucus (paired $t$-test, $\mathrm{p}<0.003$ ). However, adhesion to BSA and to MPS was similar to that observed on the skin mucus of male brown trout (paired $t$-test $\mathrm{p}>0.05$ ), and was statistically different in only 5 bacterial isolates between BSA and male skin mucus and in another 5 between MPS and male skin mucus (Student's $t$-test, $\mathrm{p}<0.05$ ). The adhesion to polystyrene was also similar to that measured on the skin mucus of male brown trout (paired $t$-test, $\mathrm{p}>0.05)$, except $A$. sobria LE 51, which had a lower adhesion to polystyrene than male trout mucus, and P. fluorescens LE 141, which had a lower adhesion to polystyrene than both male and female trout mucus (Student's $t$-test, $\mathrm{p}<0.05$ ). A positive correlation between adhesion to male brown trout mucus preparations and polystyrene was detected (Pearson correlation coefficient, $\mathrm{r}=$ $0.7408 ; \mathrm{p}=0.0014,1$-tailed).

The adhesion of Saprolegnia parasitica cysts to the skin mucus of male brown trout was high $(88.9$ $\pm 6.8 \%$ ) and greater than adhesion to female skin mucus $(75.5 \pm 7.5 \%)$. No significant differences were observed between adhesion of cysts to the skin mucus of male brown trout and the other substrates (Student's $t$-test, p > 0.05; Fig. 1).

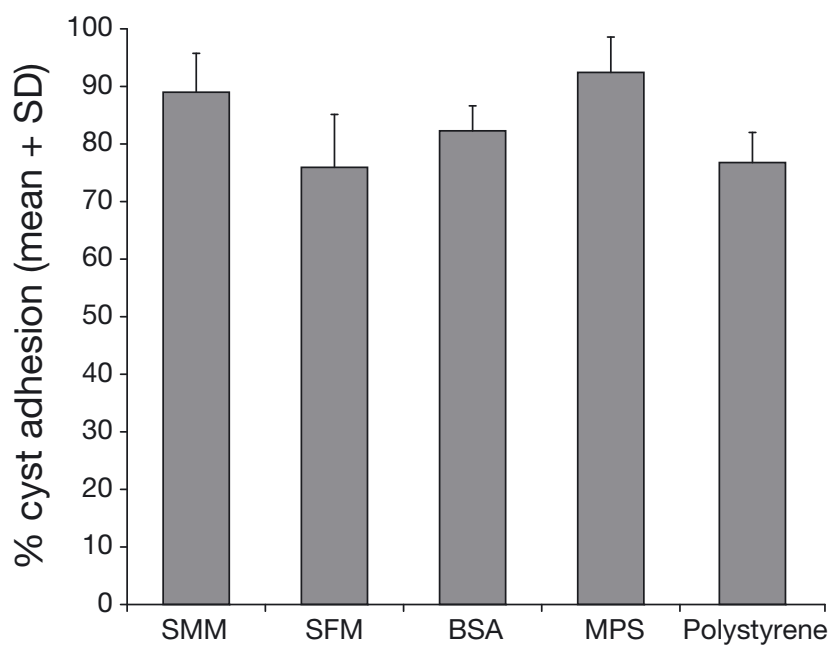

Fig. 1. Saprolegnia parasitica. Percentage of cysts (mean + $\mathrm{SD}$ of 3 experiments) adhering to the skin mucus of male (SMM) and female brown trout (SMF), to bovine serum albumin (BSA), mucin from porcine stomach (MPS) and polystyrene

Table 2. Percentage adhesion (mean \pm SD of 3 experiments) by 15 bacterial isolates to the skin mucus of male (SMM) and female brown trout (SMF), and to bovine serum albumin (BSA), mucin from porcine stomach (MPS) and polystyrene. Values in bold indicate significant differences $(p<0.05)$ with greater adhesion of bacteria to SMM than to BSA, MPS, or polystyrene

\begin{tabular}{|c|c|c|c|c|c|c|}
\hline \multirow{2}{*}{ Species } & \multirow{2}{*}{ Isolate } & \multirow{2}{*}{\multicolumn{3}{|c|}{$\begin{array}{c}\text { \% bacterial adhesion } \\
\text { BSA }\end{array}$}} & \multirow[b]{2}{*}{ MPS } & \multirow[b]{2}{*}{ Polystyrene } \\
\hline & & & & & & \\
\hline Aeromonas sobria & LE 51 & $2.02 \pm 1.22$ & $1.63 \pm 0.20$ & $1.19 \pm 1.55$ & $6.82 \pm 0.98$ & $1.74 \pm 0.02$ \\
\hline Aeromonas sobria & LE 74 & $3.48 \pm 0.36$ & $2.82 \pm 0.61$ & $2.48 \pm 0.13$ & $2.99 \pm 0.10$ & $2.65 \pm 0.32$ \\
\hline Aeromonas sobria & LE 76 & $1.66 \pm 0.55$ & $1.36 \pm 2.04$ & $1.61 \pm 0.27$ & $8.55 \pm 0.11$ & $1.45 \pm 0.12$ \\
\hline Pantoea agglomerans & LE 35 & $9.99 \pm 0.92$ & $7.55 \pm 2.32$ & $9.86 \pm 0.09$ & $7.98 \pm 0.12$ & $11.35 \pm 0.06$ \\
\hline Pantoea agglomerans & LE 36 & $4.59 \pm 0.17$ & $3.65 \pm 0.52$ & $3.59 \pm 0.16$ & $3.32 \pm 0.04$ & $3.92 \pm 0.22$ \\
\hline Pantoea agglomerans & LE 37 & $2.28 \pm 0.19$ & $2.07 \pm 0.25$ & $1.58 \pm 0.15$ & $1.51 \pm 0.47$ & $2.51 \pm 0.13$ \\
\hline Pseudomonas fluorescens & LE 89 & $2.89 \pm 0.19$ & $3.01 \pm 0.71$ & $2.80 \pm 1.37$ & $2.56 \pm 1.05$ & $3.62 \pm 0.11$ \\
\hline Pseudomonas fluorescens & LE 98 & $2.95 \pm 1.06$ & $2.56 \pm 0.39$ & $3.66 \pm 0.36$ & $2.75 \pm 0.18$ & $3.14 \pm 0.02$ \\
\hline Pseudomonas fluorescens & LE 122 & $3.99 \pm 0.54$ & $2.59 \pm 0.37$ & $2.82 \pm 0.33$ & $2.79 \pm 0.25$ & $3.83 \pm 0.08$ \\
\hline Pseudomonas fluorescens & LE 141 & $15.27 \pm 1.06$ & $13.26 \pm 0.23$ & $6.87 \pm 0.44$ & $9.21 \pm 0.42$ & $6.77 \pm 0.29$ \\
\hline Pseudomonas fluorescens & LE 143 & $3.01 \pm 0.67$ & $1.99 \pm 0.43$ & $2.13 \pm 0.19$ & $1.9 \pm 0.17$ & $1.59 \pm 0.01$ \\
\hline Serratia fonticola & LE 52 & $4.15 \pm 0.96$ & $3.43 \pm 0.25$ & $4.86 \pm 0.24$ & $3.99 \pm 0.37$ & $4.51 \pm 0.22$ \\
\hline Xanthomonas retroflexus & LE 38 & $3.01 \pm 0.55$ & $2.27 \pm 0.40$ & $1.83 \pm 0.13$ & $2.19 \pm 0.59$ & $2.68 \pm 0.02$ \\
\hline Yersinia kristensenii & LE 54 & $4.71 \pm 0.53$ & $3.43 \pm 1.12$ & $3.6 \pm 0.09$ & $2.79 \pm 0.50$ & $4.89 \pm 0.09$ \\
\hline Yersinia kristensenii & LE 58 & $3.47 \pm 1.04$ & $2.84 \pm 1.04$ & $2.72 \pm 0.73$ & $2.15 \pm 0.00$ & $4.17 \pm 0.52$ \\
\hline
\end{tabular}


Exclusion, competition and displacement tests

The results of these tests are shown in Table 3. Under exclusion conditions (adding bacteria to skin mucus before cysts), the adhesion of Saprolegnia parasitica cysts was significantly reduced by 13 of the 15 bacterial isolates (Student's $t$-test, $\mathrm{p}<$ 0.05), but with different numbers of bacterial cells.
Four of the bacterial isolates achieved this significant reduction of cyst adhesion up to the third dilution $\left(2.5 \times 10^{7}\right.$ bacteria $), 4$ up to the fourth $\left(2.6 \times 10^{6}\right.$ bacteria $), 3$ up to the fifth $\left(2.5 \times 10^{5}\right.$ bacteria) and 2 up to the sixth $\left(2.5 \times 10^{4}\right.$ bacteria $)$. This last group of isolates belonged to the isolates Aeromonas sobria LE 76 and Pseudomonas fluorescens LE 141. Significant percent reductions in

Table 3. Saprolegnia parasitica. Percentage reduction of cyst adhesion to the skin mucus of male brown trout in the presence of different numbers of cells of 15 bacterial isolates under exclusion, competition and displacement conditions. Values in bold indicate the significant \% reduction in the adhesion of $S$. parasitica cysts compared to controls (without bacteria) achieved by the minimum effective numbers of bacteria

\begin{tabular}{|c|c|c|c|c|c|}
\hline \multirow[t]{2}{*}{ Species } & \multirow[t]{2}{*}{ Isolate } & \multirow[t]{2}{*}{ No. of cells } & \multicolumn{3}{|c|}{$\%$ reduction of cyst adhesion -} \\
\hline & & & Exclusion & Competition & Displacement \\
\hline Aeromonas sobria & LE 51 & $\begin{array}{l}2.5 \times 10^{7} \\
2.5 \times 10^{6} \\
2.5 \times 10^{5}\end{array}$ & $\begin{array}{l}65.66 \\
31.81 \\
\mathbf{1 4 . 1 2}\end{array}$ & $\begin{array}{l}84.07 \\
79.35 \\
\mathbf{6 1 . 1 3}\end{array}$ & $\begin{array}{l}\mathbf{9 . 6 3} \\
8.07 \\
0.86\end{array}$ \\
\hline Aeromonas sobria & LE 74 & $\begin{array}{l}2.5 \times 10^{7} \\
2.5 \times 10^{6} \\
2.5 \times 10^{5} \\
2.5 \times 10^{4}\end{array}$ & $\begin{array}{c}64.15 \\
35.06 \\
\mathbf{1 6 . 4 4} \\
4.25\end{array}$ & $\begin{array}{l}83.61 \\
77.34 \\
73.61 \\
\mathbf{3 6 . 1 3}\end{array}$ & $\begin{array}{c}20.45 \\
\mathbf{1 6 . 0 5} \\
8.62 \\
0\end{array}$ \\
\hline Aeromonas sobria & LE 76 & $\begin{array}{l}2.5 \times 10^{7} \\
2.5 \times 10^{6} \\
2.5 \times 10^{5} \\
2.5 \times 10^{4}\end{array}$ & $\begin{array}{l}78.25 \\
61.46 \\
34.84 \\
\mathbf{1 3 . 7 4}\end{array}$ & $\begin{array}{l}88.03 \\
81.07 \\
81.88 \\
\mathbf{7 2 . 8 3}\end{array}$ & $\begin{array}{c}28.16 \\
\mathbf{2 1 . 1 7} \\
15.79 \\
9.36\end{array}$ \\
\hline Pantoea agglomerans & LE 35 & $\begin{array}{l}2.5 \times 10^{7} \\
2.5 \times 10^{6} \\
2.5 \times 10^{5}\end{array}$ & $\begin{array}{c}5.98 \\
3.67 \\
2\end{array}$ & $\begin{array}{c}69.86 \\
32.94 \\
\mathbf{7 . 4 2}\end{array}$ & $\begin{array}{c}13.94 \\
8.78 \\
8.40\end{array}$ \\
\hline Pantoea agglomerans & LE 36 & $\begin{array}{l}2.5 \times 10^{7} \\
2.5 \times 10^{6}\end{array}$ & $\begin{array}{c}13.91 \\
0\end{array}$ & $\begin{array}{l}60.97 \\
\mathbf{5 5 . 6 7}\end{array}$ & $\begin{array}{c}\mathbf{8 . 4 7} \\
0\end{array}$ \\
\hline Pantoea agglomerans & LE 37 & $\begin{array}{l}2.5 \times 10^{7} \\
2.5 \times 10^{6}\end{array}$ & $\begin{array}{l}8.80 \\
3.75\end{array}$ & $\begin{array}{l}63.55 \\
\mathbf{5 7 . 3 0}\end{array}$ & $\begin{array}{l}6.17 \\
3.53\end{array}$ \\
\hline Pseudomonas fluorescens & LE 89 & $\begin{array}{l}2.5 \times 10^{7} \\
2.5 \times 10^{6} \\
2.5 \times 10^{5}\end{array}$ & $\begin{array}{l}35.53 \\
15.76 \\
\mathbf{1 0 . 2 1}\end{array}$ & $\begin{array}{l}77.87 \\
\mathbf{5 6 . 1 5} \\
13.85\end{array}$ & $\begin{array}{c}\mathbf{2 0 . 2 4} \\
9.98 \\
10.30\end{array}$ \\
\hline Pseudomonas fluorescens & LE 98 & $\begin{array}{l}2.5 \times 10^{7} \\
2.5 \times 10^{6}\end{array}$ & $\begin{array}{l}10.64 \\
\mathbf{1 0 . 6 3}\end{array}$ & $\begin{array}{l}\mathbf{7 3 . 6 6} \\
48.96\end{array}$ & $\begin{array}{l}5.00 \\
0.34\end{array}$ \\
\hline Pseudomonas fluorescens & LE 122 & $\begin{array}{l}2.5 \times 10^{7} \\
2.5 \times 10^{6}\end{array}$ & $\begin{array}{l}51.90 \\
\mathbf{3 1 . 7 9}\end{array}$ & $\begin{array}{l}42.94 \\
\mathbf{3 7 . 5 6}\end{array}$ & $\begin{array}{c}\mathbf{5 . 2 4} \\
0\end{array}$ \\
\hline Pseudomonas fluorescens & LE 141 & $\begin{array}{l}2.5 \times 10^{7} \\
2.5 \times 10^{6} \\
2.5 \times 10^{5} \\
2.5 \times 10^{4}\end{array}$ & $\begin{array}{l}42.08 \\
37.93 \\
36.17 \\
\mathbf{1 0 . 2 7}\end{array}$ & $\begin{array}{c}83.80 \\
72.37 \\
\mathbf{3 2 . 2 3} \\
7.78\end{array}$ & $\begin{array}{c}13.83 \\
8.68 \\
0 \\
6.09\end{array}$ \\
\hline Pseudomonas fluorescens & LE 143 & $\begin{array}{l}2.5 \times 10^{7} \\
2.5 \times 10^{6} \\
2.5 \times 10^{5}\end{array}$ & $\begin{array}{c}32.67 \\
\mathbf{1 4 . 0 5} \\
6.41\end{array}$ & $\begin{array}{l}75.67 \\
63.55 \\
\mathbf{3 6 . 1 4}\end{array}$ & $\begin{array}{c}0.87 \\
0 \\
0\end{array}$ \\
\hline Serratia fonticola & LE 52 & $\begin{array}{l}2.5 \times 10^{7} \\
2.5 \times 10^{6}\end{array}$ & $\begin{array}{l}\mathbf{8 . 5 0} \\
4.61\end{array}$ & $\begin{array}{l}56.71 \\
\mathbf{3 9 . 6 4}\end{array}$ & $\begin{array}{c}7.46 \\
0\end{array}$ \\
\hline Xanthomonas retroflexus & LE 38 & $\begin{array}{l}2.5 \times 10^{7} \\
2.5 \times 10^{6} \\
2.5 \times 10^{5}\end{array}$ & $\begin{array}{c}\mathbf{1 9 . 7 2} \\
7.71 \\
12.48\end{array}$ & $\begin{array}{l}83.35 \\
74.51 \\
\mathbf{4 4 . 1 8}\end{array}$ & $\begin{array}{c}\mathbf{1 0 . 9 7} \\
10.27 \\
7.76\end{array}$ \\
\hline Yersinia kristensenii & LE 54 & $\begin{array}{l}2.5 \times 10^{7} \\
2.5 \times 10^{6}\end{array}$ & $\begin{array}{l}20.13 \\
\mathbf{1 3 . 5 6}\end{array}$ & $\begin{array}{l}52.59 \\
\mathbf{4 9 . 7 8}\end{array}$ & $\begin{array}{l}\mathbf{9 . 3 7} \\
5.92\end{array}$ \\
\hline Yersinia kristensenii & LE 58 & $\begin{array}{l}2.5 \times 10^{7} \\
2.5 \times 10^{6}\end{array}$ & $\begin{array}{c}\mathbf{1 5 . 0 0} \\
5.60\end{array}$ & $\begin{array}{l}50.68 \\
\mathbf{3 6 . 0 6}\end{array}$ & $\begin{array}{c}4.89 \\
0\end{array}$ \\
\hline
\end{tabular}


the adhesion of $S$. parasitica cysts ranged between 78.25 and $8.5 \%$.

In the competition tests (adding bacteria and cysts simultaneously to the mucus), the adhesion of the cysts was significantly reduced by all bacterial isolates tested (Student's $t$-test, $\mathrm{p}<0.05$ ), differing again in the number of cells to achieve this. One of the bacterial isolates reduced this adhesion up to the third dilution $\left(2.5 \times 10^{7}\right.$ bacteria $), 7$ did so up to the fourth $\left(2.5 \times 10^{6}\right.$ bacteria $), 5$ up to the fifth $\left(2.5 \times 10^{5}\right.$ bacteria) and 2 up to the sixth $\left(2.5 \times 10^{4}\right.$ bacteria $)$. These last 2 isolates were Aeromonas sobria LE 74 and LE 76. Significant percent reductions in the adhesion of Saprolegnia parasitica cysts ranged between 88.03 and $7.42 \%$.

In the displacement tests (adding cysts to the mucus and then bacteria), only 8 of the 15 isolates tested were able to significantly reduce the adhesion of cysts to skin mucus (Student's $t$-test, $\mathrm{p}<0.05$ ). Six of them achieved it up to the third dilution $\left(2.5 \times 10^{7}\right.$ bacteria) and 2 up to the fourth $\left(2.5 \times 10^{6}\right.$ bacteria). These latter isolates were again Aeromonas sobria LE 74 and LE 76. Significant percent reductions in the adhesion of Saprolegnia parasitica cysts ranged between 28.16 and $5.24 \%$. Fig. 2 shows the percentage reduction of $S$. parasitica cyst adhesion achieved by the best 4 of the 15 bacterial isolates in all the conditions tested.

\section{DISCUSSION}

A high proportion of the bacteria tested (15 out of 21) did not adversely affect rainbow trout. The isolates with pathogenic effects belonged to Aeromonas sobria and $A$. popoffii and caused lesions in internal organs and/or mortality. A. popoffii does not appear to have been described as pathogenic for fish, although some virulence factors have been reported (Soler et al. 2002). In contrast, certain isolates of $A$. sobria have been described as causing disease in fish such as gizzard shad Dorosoma cepedianum and perch Perca fluviatilis (Austin \& Austin 2007).

In contrast to the pathogenic Aeromonas sobria isolates tested in this study, other isolates of this species were not pathogenic for rainbow trout, nor were those belonging to the species Pantoea agglomerans, Pseudomonas fluorescens, Serratia fonticola, Xanthomonas retroflexus and Yersinia kristensenii. However other authors have found pathogenic strains of P. agglomerans and P. fluorescens (Bly et al. 1997, Austin \& Austin 2007).

The absence of pathogenicity of certain bacterial isolates belonging to species that cause diseases in fish, as well as their usefulness as probiotics against several pathogens, has been previously demonstrated in rainbow trout. For example, Irianto \& Austin (2002) did so with an Aeromonas hydrophila isolate against furunculosis, and Brunt \& Austin (2005) and Brunt et al. (2007) assessed the effectiveness of an A. sobria isolate to control several diseases, including lactococcosis, streptococcosis and furunculosis. However, it may become necessary to assess whether the 15 bacteria that were not pathogenic for rainbow trout would be equally benign against other fish species, particularly other salmonids, if they were intended to be used for biological control.

The adhesion of bacteria to the skin mucus of fish is a desirable characteristic if they are to be used in biological control of a disease (Chabrillón et al. 2005). In the present study, the adhesion to the skin mucus of brown trout of the bacteria tested was low, with percentages of adhesion not higher than $15.3 \%$. The most adhesive isolate was Pseudomonas fluorescens LE 141, followed by Pantoea
Fig. 2. Saprolegnia parasitica. Percentage reduction of cyst adhesion (mean + SD of 3 experiments) to the skin mucus of male brown trout, in the presence of the best 4 of 15 bacterial isolates, in at least 2 of the 3 conditions tested (exclusion, competition and displacement); results are relative to the adhesion of cysts in the controls (with no bacteria). ${ }^{*}$ Indicate the minimum numbers of bacteria which significantly reduced the adhesion of $S$. parasitica cysts 
agglomerans LE 35. The limited adhesion of bacteria to fish mucus is in agreement with the results of previous studies (Chabrillón et al. 2005, 2006, Balcázar et al. 2007), with adhesion being lower on skin mucus than on gut mucus of rainbow trout and other fish species on some occasions (Chabrillón et al. 2006, Balcázar et al. 2007, 2008). We observed that there was greater adhesion of bacteria to the skin mucus of male than of female brown trout, and this may have implications for the future treatment of fish with inhibitory bacteria against Saprolegnia parasitica. Thus, female trout would need to be treated with higher concentrations of bacteria.

The non-specific binding of bacteria can be measured by testing their adhesion to BSA because, as Ouwehand et al. (2003) stated, it is unlikely that bacteria develop a specific affinity for this protein. In our study, the adhesion of bacteria to the skin mucus of male trout was in general not higher than to BSA. This is in agreement with Balcázar et al. $(2007,2008)$, who found differences only between adhesion to intestinal mucus of rainbow trout and to BSA, but not using skin mucus; in contrast, Nikoskelainen et al. (2001) found differences in the adhesion between rainbow trout mucus of both origins and BSA.

We found that the adhesion of bacteria to MPS was generally lower than the adhesion to male brown trout skin mucus. This suggests that the adhesion of bacteria to mucus has no host specificity and depends more on the bacterial isolate than on the kind of mucus tested. The lack of host specificity was also observed by other authors (Nikoskelainen et al. 2001, Rinkinen et al. 2003, Chabrillón et al. 2005, 2006), although it would be a desirable characteristic in any bacteria to be used in biological control (Rinkinen et al. 2003, Chabrillón et al. 2005).

Adhesion to polystyrene was found to be generally similar to that observed to skin mucus of male trout in this study, as also shown elsewhere (Nikoskelainen et al. 2001, Balcázar et al. 2007). The strong adhesion of bacteria to polystyrene has been related to hydrophobic interactions (Balcázar et al. 2007, 2008), and some authors have reported that strong hydrophobicity is an indicator of good binding ability (Wadstroum et al. 1987, Balcázar et al. 2007, Pérez-Sánchez et al. 2011). In our study, a correlation between adhesion to polystyrene and to the skin mucus of trout was found, opposite to the results of Balcázar et al. (2007). However, Ouwehand et al. (1999) stated that there was no relationship between a strong capacity for adhesion and hydrophobic interactions. Another indicator of good binding ability of bacteria could be auto-aggregation (Collado et al. 2008).
In the present study, a new technique to study the adhesion of cysts of Saprolegnia parasitica to skin mucus of trout and also the ability of bacteria to reduce this adhesion under different conditions has been described. The strong binding of $S$. parasitica cysts to the skin mucus of brown trout might be due to the presence of hooked hairs in bundles, which has been considered as an adaptation of the most pathogenic strains in order to achieve attachment to the host (Pickering \& Willoughby 1982, Beakes 1983), although we have not found differences between the adhesion of $S$. parasitica and $S$. diclina isolates to skin mucus (data not shown), so other factors such as the glycoproteins surrounding the spines may also be involved in the attachment (Burr \& Beakes 1994). The adhesion of cysts was higher to the skin mucus of male brown trout than to the skin mucus of females. This may be related to the higher incidence of saprolegniosis in male trout found by other authors (Aller-Gancedo \& Fernández-Díez 1987). Another hypothesis to explain the greater predisposition of male brown trout to become infected is the smaller amount of mucus on the skin of males, which Pickering (1977) associated with their higher plasmatic levels of androgens and which might reduce the level of protection from the skin.

The ability of bacteria to reduce the adhesion of cysts to the skin mucus of trout varied in accordance with the conditions of the experiment. In competition and exclusion tests, all, or nearly all, of the isolates succeeded in impeding to some extent the binding of Saprolegnia parasitica. However, only half of the bacterial isolates managed to displace the cysts from skin mucus, and, even among these, higher bacterial concentrations were needed for this effect. This may be because of the strong ability of the $S$. parasitica cysts to adhere, which makes it difficult to displace them once they are attached. Other authors have performed similar assays on skin and gut mucus of different fish species, but with bacterial pathogens, and obtained different results (Vine et al. 2004, Chabrillón et al. 2005, 2006, Balcázar et al. 2007, 2008, Sica et al. 2012).

The bacterial isolates which most effectively reduced the adhesion of Saprolegnia parasitica cysts to the skin mucus of male brown trout were those belonging to the species Aeromonas sobria, followed by some Pseudomonas fluorescens isolates. The $P$. fluorescens LE 141 isolate, which was the most adhesive to the skin mucus of trout, achieved considerable exclusion and competition of binding by cysts, but it did not displace them from the mucus. 
The bacterial isolates used in this study that were not pathogenic for trout and had a strong ability to reduce the adhesion of Saprolegnia parasitica cysts to skin mucus might be good candidates for use in the biological control of saprolegniosis. Further studies are needed to determine the in vivo inhibitory effect of these bacteria against saprolegniosis that has been predicted by previous studies.

Acknowledgements. This work formed part of research project AGL2006-03374/ACU financed by the Spanish Ministerio de Educación y Ciencia and the European Regional Development Fund, and research project AGL 2009-10151, financed by the Ministerio de Educación y Ciencia. M.T.C.-G. was supported by a fellowship from the Consejería de Educación de la Junta de Castilla y León, co-financed by the European Social Fund. We thank the Servicio Territorial de Medio Ambiente de la Junta de Castilla y León for help in the collection of brown trout from the Vegas del Condado hatchery, and the 'Los Leoneses' fish farm at Castrillo del Condado in the Province of León for providing the rainbow trout. We also thank Prof. Dr. D. Steinhagen (University of Veterinary Medicine, Hannover) and his research team for their help with the techniques related to adhesion assays with Syto 9.

\section{LITERATURE CITED}

Aller-Gancedo JM, Fernández-Díez M (1987) Saprolegniosis en la trucha común (Salmo trutta) de los ríos de León (España). Med Vet 4:181-184

Austin B, Austin DA (2007) Bacterial fish pathogens. Diseases of farmed and wild fish, 4th edn. Praxis Publishing, Chichester

Balcázar JL, Vendrell D, de Blas I, Ruiz-Zarzuela I, Girones O, Múzquiz JL (2007) In vitro competitive adhesion and production of antagonistic compounds by lactic acid bacteria against fish pathogens. Vet Microbiol 122:373-380

Balcázar JL, Vendrell D, de Blas I, Ruiz-Zarzuela I, Múzquiz JL, Girones O (2008) Characterization of probiotic properties of lactic acid bacteria isolated from intestinal microbiota of fish. Aquaculture 278:188-191

$>$ Beakes GW (1983) A comparative account of cyst coat ontogeny in saprophytic and fish-lesion (pathogenic) isolates of the Saprolegnia diclina-parasitica complex. Can J Bot 61:603-625

- Bly JE, Quiniou SMA, Lawson LA, Clem LW (1997) Inhibition of Saprolegnia pathogenic for fish by Pseudomonas fluorescens. J Fish Dis 20:35-40

Brunt J, Austin B (2005) Use of a probiotic to control lactococcosis and streptococcosis in rainbow trout, Oncorhynchus mykiss (Walbaum). J Fish Dis 28:693-701

Brunt J, Newaj-Fyzul A, Austin B (2007) The development of probiotics for the control of multiple bacterial diseases of rainbow trout, Oncorhynchus mykiss (Walbaum). J Fish Dis 30:573-579

Burr AW, Beakes GW (1994) Characterization of zoospore and cyst surface structure in saprophytic and fish pathogenic Saprolegnia species (oomycete fungal protists). Protoplasma 181:142-163
Carbajal-González MT, Fregeneda-Grandes JM, SuárezRamos S, Rodríguez Cadenas F, Aller-Gancedo JM (2011) Bacterial skin flora variation and in vitro inhibitory activity against Saprolegnia parasitica in brown trout and rainbow trout. Dis Aquat Org 96:125-135

Chabrillón M, Rico RM, Balebona MC, Moriñigo MA (2005) Adhesion to sole, Solea senegalensis Kaup, mucus of microorganisms isolated from farmed fish, and their interaction with Photobacterium damselae subsp. piscicida. J Fish Dis 28:229-237

Chabrillón M, Ouwehand AC, Díaz-Rosales P, Arijo S, Martínez-Manzanares E, Balebona MC, Moriñigo MA (2006) Adhesion of lactic acid bacteria to mucus of farmed gilthead seabream, and interactions with fish pathogenic microorganisms. Bull Eur Assoc Fish Pathol 26:202-210

> Collado MC, Meriluoto J, Salminen S (2008) Adhesion and aggregation properties of probiotic and pathogen strains. Eur Food Res Technol 226:1065-1073

> Fregeneda-Grandes JM, Fernández-Díez M, Aller-Gancedo JM (2000) Ultrastructural analysis of Saprolegnia secondary zoospore cyst ornamentation from infected wild brown trout, Salmo trutta L., and river water indicates two distinct morphotypes amongst long-spined isolates. J Fish Dis 23:147-160

Hatai K, Willoughby LG (1988) Saprolegnia parasitica from rainbow trout inhibited by the bacterium Pseudomonas fluorescens. Bull Eur Assoc Fish Pathol 8:27-29

Hussein MA, Hatai K (2001) In vitro inhibition of Saprolegnia by bacteria isolated from lesions of salmonids with saprolegniasis. Fish Pathol 36:73-78

> Irianto A, Austin B (2002) Use of probiotics to control furunculosis in rainbow trout, Oncorhynchus mykiss (Walbaum). J Fish Dis 25:333-342

Khosravi AR, Shokri H, Sharifrohani M, Mousavi HE, Moosavi Z (2012) Evaluation of the antifungal activity of Zataria multiflora, Geranium herbarium, and Eucalyptus camaldolensis essential oils on Saprolegnia parasiticainfected rainbow trout (Oncorhynchus mykiss) eggs. Foodborne Pathog Dis 9:674-679

Lategan MJ, Gibson LF (2003) Antagonistic activity of Aeromonas media strain A199 against Saprolegnia sp., an opportunistic pathogen of the eel, Anguilla australis Richardson. J Fish Dis 26:147-153

> Muzzarelli RAA, Muzzarelli C, Tarsi R, Miliani M, Gabbanelli F, Cartolari M (2001) Fungistatic activity of modified chitosans against Saprolegnia parasitica. Biomacromolecules 2:165-169

Neuhaus H, van der Marel M, Caspari N, Meyer W, Enss ML, Steinhagen D (2007) Biochemical and histochemical study on the intestinal mucosa of the common carp Cyprinus carpio L., with special consideration of mucin glycoproteins. J Fish Biol 70:1523-1534

Nikoskelainen S, Salminen S, Bylund G, Ouwehand AC (2001) Characterization of the properties of human- and dairy-derived probiotics for prevention of infectious diseases in fish. Appl Environ Microbiol 67:2430-2435

Nurhajati J, Atira, Aryantha INP, Kadek Indah DG (2012) The curative action of Lactobacillus plantarum FNCC 226 to Saprolegnia parasitica A3 on catfish (Pangasius hypophthalamus Sauvage). Int Food Res J 19: 1723-1727

Ouwehand AC, Kirjavainen PV, Grönlund MM, Isolauri E, Salminen SJ (1999) Adhesion of probiotic micro-organisms to intestinal mucus. Int Dairy J 9:623-630 
Ouwehand AC, Båtsman A, Salminen S (2003) Probiotics for the skin: a new area of potential application? Lett Appl Microbiol 36:327-331

Pérez-Sánchez T, Balcázar JL, García Y, Halaihel N and others (2011) Identification and characterization of lactic acid bacteria isolated from rainbow trout, Oncorhynchus mykiss (Walbaum), with inhibitory activity against Lactococcus garvieae. J Fish Dis 34:499-507

Pickering AD (1977) Seasonal changes in the epidermis of the brown trout, Salmo trutta (L.). J Fish Biol 10:561-566

Pickering AD, Willoughby LG (1982) Saprolegnia infections of salmonid fish. In: Roberts RJ (ed) Microbial diseases of fish. Academic Press, London, p 271-297

Ran C, Carrias A, Williams MA, Capps N and others (2012) Identification of Bacillus strains for biological control of catfish pathogens. PLoS ONE 7:e45793

Rinkinen M, Westermarck E, Salminen S, Ouwehand AC (2003) Absence of host specificity for in vitro adhesion of probiotic lactic acid bacteria to intestinal mucus. Vet Microbiol 97:55-61

Sica MG, Brugnoni LI, Marucci PL, Cubitto MA (2012) Char-

Editorial responsibility: David Bruno,

Aberdeen, UK acterization of probiotic properties of lactic acid bacteria isolated from an estuarine environment for application in rainbow trout (Oncorhynchus mykiss, Walbaum) farming. Ant Leeuwenhoek 101:869-879

Soler L, Figueras MJ, Chacón MR, Vila J, Marco F, Martínez-Murcia AJ, Guarro J (2002) Potential virulence and antimicrobial susceptibility of Aeromonas popoffii recovered from freshwater and seawater. FEMS Immunol Med Microbiol 32 (3): 243-247

Vine NG, Leukes WD, Kaiser H, Daya S, Baxter J, Hecht T (2004) Competition for attachment of aquaculture candidate probiotic and pathogenic bacteria on fish intestinal mucus. J Fish Dis 27:319-326

Wadstroum T, Andersson K, Sydow M, Axelsson L, Lindgren S, Gullmar B (1987) Surface properties of lactobacilli isolated from the small intestine of pigs. J Appl Microbiol 62:513-520

Zhang SJ, Yang XL, Li D, Li Y, Gao P (2008) Screening of antagonistic bacterium strain against saprolegniosis and the preliminary study of in vitro antagonistic activity. Acta Hydrobiol Sin 32:301-307

Submitted: August 1, 2012; Accepted: January 29, 2013 Proofs received from author(s): March 31, 2013 